\title{
Discovery Abuse Under the Federal Rules: Causes and Cures
}

The adoption of liberal discovery provisions ${ }^{1}$ was "one of the most significant innovations of the Federal Rules of Civil Procedure."2 These provisions have given rise to widespread discovery abuse. ${ }^{3}$ This Note suggests a coherent framework for analyzing abuse of civil discovery ${ }^{4}$ and for examining the adequacy of the Rules in coping with such abuse.

First, the Note shows that externalities ${ }^{8}$ will result in inefficiently high discovery expenditures when, as currently, a litigant must absorb the costs of responding to the discovery requests of his opponent. The Note then shows that the current Rules create an incentive for a party to maximize the difference between the costs of discovery he incurs and those imposed upon his opponent. It then uses game theory to argue that this incentive places the parties in the "Prisoner's Dilemma," and that the litigants as well as society will therefore benefit from external restraints upon discovery. ${ }^{7}$ Next, the Note examines the degree to which the Rules have allowed judicial intervention to function as an efficient restraint in the discovery process and explains the increasing concern of the Rules' drafters with

1. See generally FED. R. CIV. P. 26-37 (discovery provisions).

2. Hickman v. Taylor, 329 U.S. 495,500 (1947).

3. Amendments to the discovery provisions of the Rules in 1970 and 1980 , as well as those proposed in 1982, reflect concern over such abuse. See infra pp. 372-73. A number of courts and commentators have also argued that discovery abuse" is a significant problem. See, e.g., Herbert v. Lando, 441 U.S. 153, 179 (1979) (Powell, J., concurring) (discovery has been "not infrequently exploited to the disadvantage of justice"); Brazil, The Adversary Character of Civil Discovery: A Critique and Proposals for Change, 31 VAND. L. REV. 1295, 1304 (1978) (current practice "frustrating to a significant extent" goals of discovery); Renfrew, Discovery Sanctions: A Judicial Perspective, 67 CALIF. L. REV. 264, 264 (1979) (abuse of discovery difficult to detect but widespread).

4. This Note undertakes no specific examination of discovery in criminal cases. The discovery opportunities in criminal cases are much narrower than those in civil cases. For a general discussion of criminal discovery, see Norton, Criminal Discovery Experience Under the ABA Standards, 11 LOY. U. CHI. L.J. 661 (1980).

5. An externality is a cost or benefit resulting from a decisionmaker's activity that does not accrue to the decisionmaker and is thus "external" to his decisionmaking process. See J. HIRSHLEIFER, PRICE THEORY AND APPLICATIONS 532 (2d ed. 1980). This Note's analysis concentrates upon external costs in discovery.

6. For a discussion of game theory and the Prisoner's Dilemma, see infra pp. 362-63.

7. No previous analysis of discovery has used either an economic model to analyze a party's decision whether to settle a case or the game-theory model of the Prisoner's Dilemma.

Of those adopting an economic approach to legal problems, Carrington is closest to the view developed here: "[P]roposals [for discovery reform] attempt to get the same information at less cost by increasing the amount of judicial participation and coercion in the process, and diminishing the reliance upon the parties privately to conform their behavior to the prescribed standards of procedure." Carrington, Adjudication as a Private Good: A Comment, 8 J. LEGaL STUD. 303, 309 (1979). Carrington, however, does not seek to explain why judicial participation and coercion should be effective, nor why reliance upon the private incentives for parties to follow the prescribed standards of procedure is insufficient. 
providing such restraints as a result of certain trends in modern federal causes of action. The Note concludes with some suggestions for further improving the efficiency of the discovery process.

\section{The Externality Problem}

The current allocation of legal fees between the litigants combines with the rules governing discovery to allow a litigant to increase his opponent's costs of litigation. This "externality" results in an inefficiently high amount of discovery. Traditional economic solutions to the problem are unlikely to be successful in the limited-information context of discovery proceedings.

\section{A. The Current Allocation of Discovery Costs}

A party in an American court must generally pay his own attorneys' fees regardless of the outcome of the litigation. ${ }^{8} \mathrm{He}$ also bears the nonmonetary costs of lost time and psychological anxiety that can result from litigation. ${ }^{\circ}$ By making a request for unprivileged information "relevant to the subject matter" of the litigation, ${ }^{10}$ a party in a civil suit in federal

8. Under the "American rule," each party pays his own attorneys' fees. For a discussion of the history of this rule, see Alyeska Pipeline Serv. Co. v. Wilderness Soc'y, 421 U.S. 240, 247-57 (1975). Both the federal judiciary and Congress have created exceptions to the rule, however. See id. at 25763 (victorious plaintiff usually recovers fees in antitrust and civil rights cases, among others).

In contrast, the "Continental rule" allocates the fees of both parties to the losing party. A comparison of the discovery incentives under the two systems is beyond the scope of this Note. For acomparison of the general incentives under the two systems, see Shavell, Suit, Settlement, and Trial: A Theoretical Analysis Under Alternative Methods for the Allocation of Legal Costs, 11 J. LEGAL STUD. 55 (1982).

9. Parties to litigation generally hire an attorney to represent them, see infra note 33, but a party must himself appear in court or in deposition.

10. The Rules state:

Parties may obtain discovery regarding any matter, not privileged, which is relevant to the subject matter involved in the pending action, whether it relates to the claim or defense of the party seeking discovery or to the claim or defense of any other party . . . It is not ground for objection that the information sought will be inadmissible at the trial if the information sought appears reasonably calculated to lead to the discovery of admissible evidence.

FED. R. CIV. P. 26(b)(1). Less than a decade after the 1938 adoption of the Rules, the Supreme Court summarized this new standard in an oft-repeated passage: "We agree, of course, that the deposition-discovery rules are to be accorded a broad and liberal treatment. No longer can the timehonored cry of 'fishing expedition' serve to preclude a party from inquiring into the facts underlying his opponent's case." Hickman v. Taylor, 329 U.S. 495, 507 (1947) (footnote omitted).

The courts for the most part continue to hold this view: "Fortunately, in the search for the ultimate, TRUTH, the Federal Courts, blessed with the rules of discovery, are not shackled with strict interpretations of relevancy." Cox v. E.I. du Pont de Nemours \& Co., 38 F.R.D. 396, 398 (D.S.C. 1965). Discovery may even be used to obtain information already in the requesting party's possession on the grounds that such discovery may narrow the issues in conflict in the case. See Baim \& Blank, Inc. v. Philco Distribs., 25 F.R.D. 86, 87 (E.D.N.Y. 1957).

Even this liberality has its limits, however. One court extended the Hickman court's metaphor to chastise a party who apparently sought any papers either published by its opponent's expert witness or reviewed by him in preparation for the trial: "[I]nstead of using rod and reel, or even a reasonably sized net, [the requesting party] would drain the pond and collect the fish from the bottom. This 
court ${ }^{11}$ can impose multiple, costly obligations on his opponent. ${ }^{12}$ In response to a discovery request, a litigant must make himself available in person to answer the questions of the opposing side, ${ }^{13}$ and must, to the extent of his knowledge after a reasonable search, respond in writing to his opponent's interrogatories. ${ }^{14}$ He must allow his opponent access to his

exercise goes beyond the bounds set by the discovery rules." In re IBM Peripheral EDP Devices Antitrust Litigation, 77 F.R.D. 39, 42 (N.D. Cal. 1977).

11. The civil discovery rules of state courts are usually at least roughly similar to those of the federal courts. For a comparison of the possibilities for abuse of discovery in federal and California state courts, see Sherwood, Curbing Discovery Abuse: Sanctions Under the Federal Rules of Civil Procedure and the California Code of Civil Procedure, 21 SANTA CLARA L. REV. 567 (1981).

12. In a limited number of instances, however, a party may avoid complying with a discovery request by asserting an evidentiary privilege. See United States v. Reynolds, 345 U.S. 1, 6 (1953). For discussions of the application of various evidentiary privileges to discovery proceedings, see Herbert $v$. Lando, 441 U.S. 153 (1979) (First Amendment); United States v. Noble, 422 U.S. 225 (1975) (Fifth Amendment); United States v. Reynolds, 345 U.S. 1 (1953) (military secrets).

The discovery of an attorney's "work product" is allowed only when the requesting party has "substantial need of the materials" and cannot otherwise obtain the materials or their substantial equivalent without "undue hardship." FED. R. CIV. P. 26(b)(3). The application of this rule was recently broadened substantially in Upjohn Co. v. United States, 449 U.S. 383, 391 (1981) (workproduct rule applies to communications to attorney not only from upper management but from all employees who can, "within the scope of their employment, embroil the corporation in legal difficulties").

Discovery of the legal strategies of attorneys is prohibited. FED. R. CIV. P. 26(b)(3); see Duplan Corp. v. Moulinage \& Retorderie de Chavanoz, 509 F.2d 730, 734-35 (4th Cir. 1974), cert. denied, 420 U.S. 997 (1975).

13. Rule 30(a) states in part: "After commencement of the action, any party may take the testimony of any person, including a party, by deposition upon oral examination." FED. R. CIV. P. 30(a). Rule 31 (a) similarly allows for deposition upon written questions. See FED. R. CIV. P. 31(a).

Oral depositions are in fact the most popular discovery mechanism, accounting in one empirical study for over $40 \%$ of discovery requests. See P. CONNOLLY, E. HollEMAN \& M. KuHLMAN, JUDI. CIAL CONTROLS AND THE CIVIL LITIGATIVE PROCESS: DISCOVERY 30 (1978) [hereinafter cited as JUDICIAL CONTROLS]. The requesting party must give the responding party reasonable notice of the deposition. See Stover v. Universal Moulded Prods. Corp., 11 F.R.D. 90, 91 (E.D. Pa. 1950) (two days' notice unreasonably short). But see RCA v. Rauland Corp., 21 F.R.D. 113 (N.D. Ill. 1957) (one day's notice reasonable when both sides' counsel gathered in foreign city to take depositions).

The time of the deposition is generally scheduled according to the convenience of the responding party. See Shenker v. United States, 25 F.R.D. 96, 98 (E.D.N.Y. 1960) (never on Sundays); Walsh v. Pullman Co., 10 F.R.D. 77, 79 (S.D.N.Y. 1948) (severe attack of influenza grounds for postponing deposition); Union Cent. Life Ins. Co. v. Burger, 27 F. Supp. 556, 557 (S.D.N.Y. 1939) (sixteenyear-old's deposition to take place outside of hours when "busy at school"). Similarly, the location should be convenient for the responding party. See FED. R. CIV. P. 45(d)(2) (depositions to occur in district of service, residence, or place of business of responding party, or within $\mathbf{4 0}$ miles of the place of service, or at "other convenient place" ordered by court); see also Twardzik v. Sepauley, 286 F. Supp. 346, 350 (E.D. Pa. 1968) (rule 45(d)(2) standard provisions as support against allowing deposition location inconvenient to responding party). The general presumption is that the deposition shall take place at the residence or place of employment of the deponent. See General Leasing Co. v. Lawrence Photo-Graphic Supply, Inc., 84 F.R.D. 130, 131 (W.D. Mo. 1979); Grey v. Continental Mktg. Assocs., 315 F. Supp. 826, 832 (N.D. Ga. 1970). If the responding party is the plaintiff, however, he must generally agree to bear the expense of appearing for his deposition in the district where he filed suit. See Baird v. Quality Foods, Inc., 47 F.R.D. 212 (E.D. La. 1969). In some cases, however, courts makes exceptions to this rule. See Leist v. Union Oil Co., 82 F.R.D. 203 (E.D. Wis. 1979) (plaintiff unemployed and "impecunious"); Terry v. Modern Woodmen of America, 57 F.R.D. 141, 144 (W.D. Mo. 1972) (defendant "most able" to bear expense of plaintiff's trip).

14. Rule 33(a) states in part: "Any party may serve upon any other party written interrogatories to be answered by the party served ... . Interrogatories may, without leave of court, be served upon the plaintiff after commencement of the action and upon any other party with or after service of the 


\section{Discovery Abuse}

property, both real and personal. ${ }^{16}$ If his opponent requests that he admit a certain fact as true or a particular matter of law as decided, a litigant must make a reasonable effort to determine the veracity of the assertion before denying that it is true. ${ }^{16} \mathrm{He}$ may have to submit to a medical examination. ${ }^{17}$ The litigant must amend any response to a discovery request

\section{. . complaint upon that party." FED. R. CIV. P. 33(a).}

Interrogatories are the second most popular discovery mechanism, accounting for about $35 \%$ of the discovery requests in one empirical study. See JUDICIAL CONTROLS, supra note 13, at 30 .

If the responding party is a legal person, an agent answers the interrogatories. See FED. R. CIV. P. 33(a); see also Holland v. Minneapolis-Honeywell Regulator Co., 28 F.R.D. 595 (D.D.C. 1961) (corporation, not adverse party, chooses agent). The agent's duty to obtain information extends beyond the knowledge within his direct control. See Olmert v. Nelson, 60 F.R.D. 369, 370 (D.D.C. 1973) (information possessed by someone not a corporate officer); -Cage v. New York C.R.R., 276 F. Supp. 778 (W.D. Pa.) (information known to part of organization other than that answering interrogatory), aff'd, 386 F.2d 998 (3d Cir. 1967).

15. Rule 34(a)(1) states in part:

Any party may serve on any other party a request ... to produce and permit the party making the request, or someone acting on his behalf, to inspect and copy, any designated documents (including writings, drawings, graphs, charts, photographs, phono-records, and other data compilations from which information can be obtained . . . or to inspect and copy, test, or sample any tangible things which constitute or contain matters within the scope of Rule 26 (b) and which are in the possession, custody or control of the party upon whom the request is served ....

FED. R. CIV. P. 34(a)(1).

Rule 34(a)(2) allows the requesting party to enter onto the responding party's property to make inspections. See, e.g., Williams v. Continental Oil Co., 215 F.2d 4 (10th Cir. 1954) (survey of oil wells), cert. denied, 349 U.S. 928 (1955); Cox v. E.I. du Pont de Nemours \& Co., 38 F.R.D. 396 (D.S.C. 1965) (inspection of machine alleged to be cause of death).

Requests under rule 34 accounted for about $15 \%$ of the discovery requests in one empirical survey. See JUDICIAL CONTROLS, supra note 13 , at 30.

16. Rule 36(a) states in part:

A party may serve upon any other party a written request for the admission, for purposes of the pending action only, of the truth of any matters within the scope of Rule $26(\mathrm{~b})$. . . that relate to statements or opinions of fact or of the application of law to fact, including the genuineness of any documents described in the request. . . . An answering party may not give lack of information or knowledge as a reason for failure to admit or deny unless he states that he has made reasonable inquiry and that the information known or readily available by him is insufficient to enable him to admit or deny.

FED. R. CIV. P. 36(a).

Requests for admissions accounted for about $6 \%$ of discovery requests in one empirical study. See JUDICIAL CONTROLS, supra note 13, at 30 .

A failure to respond to a request for an admission is equivalent to making the admission. See, e.g., John Mohr \& Sons v. Apex Terminal Warehouses, Inc., 422 F.2d 638, 642 (7th Cir. 1970); DeLeon v. Ramirez, 465 F. Supp. 698, 701 (S.D.N.Y. 1979).

17. Rule 35(a) states in part:

When the mental or physical condition (including the blood group) of a party, or of a person in the custody or under the legal control of a party, is in controversy, the court in which the action is pending may order the party to submit to a physical or mental examination by a physician or to produce for examination the person in his custody or legal control. The order may be made only on motion for good cause shown and upon notice to the person to be examined and to all parties and shall specify the time, place, manner, conditions, and scope of the examination and the person or persons by whom it is to be made.

FED. R. CIV. P. 35(a).

Such requests accounted for less than $1 \%$ of discovery requests in one empirical study. See JuDicial CONTROLS, supra note 13 , at 30 . 
upon ascertaining that it is no longer accurate. ${ }^{18}$

Courts can impose a variety of sanctions on litigants who fail to comply with discovery requests. If a court issues an order compelling discovery, ${ }^{10}$ refusal by the responding party to comply may subject him to the traditional sanctions for contempt ${ }^{20}$ or the variety of other sanctions specified by the Rules. ${ }^{21}$

\section{B. Discovery and Externalities}

Discovery provides litigants with an inexpensive method of acquiring information. ${ }^{22}$ Information garnered from discovery can increase the strength of a litigant's position in settlement negotiations or his chances of victory if the case goes to trial. ${ }^{23}$ 'The litigant may also benefit if the information gained from discovery reduces his uncertainty about the likely outcome of the litigation, regardless of whether his estimate of his probability of winning the suit increases or decreases. ${ }^{24}$ Discovery may also provide information useful to the litigant outside the context of the instant litigation. $^{25}$ Finally, and most importantly for the analysis undertaken here,

18. See Voegeli v. Lewis, 568 F.2d 89, 96 (8th Cir. 1977) (change in expert's opinion on "pivotal" testimony). But see Phil Crowley Steel Corp. v. Macomber, Inc., 601 F.2d 342, 344-45 (8th Cir. 1979) (plaintiff's decision to change damages formula not sanctionable when opponent, informed four days before trial, does not protest until trial begins).

19. The requesting party generally must first move for a court order compelling compliance with the request. FED. R. Civ. P. 37(a); see Wembley, Inc. v. Diplomat Tie Co., 216 F. Supp. 565, 573 (D. Md. 1963) (motion to strike testimony for inadequate answers to interrogatories cannot be granted before court issues order compelling answers).

20. FED. R. CIv. P. 37(b)(2)(D); see Jones v. Louisiana State Bar Ass'n, 602 F.2d 94, 97 (5th Cir. 1979) (criminal contempt); Hodgson v. Mahoney, 460 F.2d 326 (1st Cir.) (civil contempt), cert. denied, 409 U.S. 1039 (1972). The contempt sanction is unavailable against a refusal to submit to a medical examination. FED. R. CIV. P. $37(\mathrm{~b})(2)(D)$.

21. See FED. R. CIV. P. 37(b) (specific sanctions for failure to respond include dismissal of case and striking portions of testimony or pleadings).

The responding party may have to absorb the expenses he incurs in contesting the motion even if the court upholds his refusal to comply. See infra p. 374.

22. If discovery provided cheaper access than other methods for all information, litigants would never use other methods of acquiring information, such as private investigators or informal interviews with witnesses.

23. Presumably it is the increase in his chances of prevailing that increases the strength of a litigant's settlement position.

24. First, a more accurate estimate of his chances of prevailing lessens the litigant's chances of mistakenly settling for less favorable terms than he is likely to receive from proceeding to trial. Second, if discovery decreases the uncertainty surrounding the litigant's estimate of his probability of prevailing at trial, the litigant will benefit from increased certainty about the trial outcome if he is risk averse.

25. The information may be useful in other litigation. See, e.g., Williams v. Johnson \& Johnson, 50 F.R.D. 31, 32 (S.D.N.Y. 1970) (sharing discovery among plaintiffs economical). But see Founding Church of Scientology v. Kelley, 77 F.R.D. 378, 380 (D.D.C. 1977) (litigants cannot use civil discovery to avoid restrictions on criminal discovery).

Some discoverable information may be useful outside the context of litigation. See Xerox Corp. v. IBM, 399 F. Supp. 451 (S.D.N.Y. 1975) (patent information); Singer Mfg. Co. v. Brother Int'l Corp., 191 F. Supp. 322 (S.D.N.Y. 1960) (discovery of sales and price data). The courts are often cautious in allowing discovery of sensitive business information, however. See, e.g., United States v. 
discovery benefits a litigant by allowing him to threaten to impose costs-in the form of burdensome requests-upon his opponent. ${ }^{26} \mathrm{~A}$ rational opponent will then offer the threatening party a more favorable settlement to avoid the costs of responding to the threatened discovery requests. ${ }^{27}$

A litigant undertakes discovery so long as the benefit to him from an additional expenditure on discovery exceeds its cost to him. ${ }^{28}$ If the litigant considering a particular discovery request received all the benefits and absorbed all the costs of that request, his choice of the level of his discovery expenditures would result in a socially efficient amount of discovery. ${ }^{29} \mathrm{He}$ would take an action only if its social benefits, all of which he would reap, exceeded its social costs, all of which he would incur. Under the current system of allocating legal costs, ${ }^{\mathbf{3 0}}$ however, a litigant does not bear the full costs that he imposes upon the other party as a result of his discovery request. ${ }^{31}$ Litigants will therefore engage in more discovery than is socially efficient. ${ }^{32}$

The problem of socially excessive discovery is exacerbated because the vast majority of litigants do not represent themselves in litigation. ${ }^{33}$ Like

United Fruit Co., 410 F.2d 553, 557 n.11 (5th Cir.) (details of company structure in divestment plan denied to competitors), cert. denied, 396 U.S. 820 (1969); Rosenblatt v. Northwest Airlines, Inc., 54 F.R.D. 21, 23 (S.D.N.Y. 1971) (discovery of defendant's financial status delayed pending withdrawal of competitor from suit).

26. For the purposes of this analysis, a discovery request is "harassing" to the extent that its benefit to the requesting party depends upon the costs of response thereby imposed upon the other party rather than upon the value of the information obtained by the requesting party.

27. See Blue Chip Stamps v. Manor Drug Stores, 421 U.S. 723, 741 (1975) (discovery requests sometimes used to gain "in terrorem increment of the settlement value"). Carrying through with such a threat may delay the completion of litigation, which may also be a relative benefit to the requesting party if he is less anxious than his opponent to terminate the litigation. See Posner, An Economic Approach to Legal Procedure and Judicial Administration, 2 J. LEGAL STUD. 399, 420-21, 455-56 (1973); Note, An Analysis of Settlement, 22 STAN. L. REV. 67, 78 (1969).

28. Of course, the litigant generally employs an attorney as his agent in legal proceedings, and it is the attorney who makes decisions concerning discovery expenditures. See infra pp. 357-58.

29. See J. HIRSHLEIFER, supra note 5, at 532-34.

30. See supra p. 353.

31. There are costs and benefits to society as a whole that are also not included in the litigant's calculations. The litigant does not pay the costs to society that result from the need to employ judges, bailiffs, and legislators to resolve his problems in court, nor does the litigant reap the benefits to the society of his contribution to law (in the form of a judicial opinion to be added to the stock of precedent) and order (in the form of a peaceful end to a dispute). These considerations are beyond the scope of this Note.

32. See J. HiRSHLEIFER, supra note 5, at 532-34.

Recently, some attorneys have sold the discovery materials they have obtained to other attorneys prosecuting similar causes of action. See Wall St. J., Dec. 20, 1982, at 19. This development appears to be legal. If the practice is upheld, one can expect that parties will increase further their discovery efforts in anticipation of later sale of the information. The property right in discovery currently accrues to the requesting party, who thus reaps the benefits while imposing the costs of gathering the information upon the responding party. The practice of selling discovery thus exacerbates the externality problem.

33. In only 202 of the 3114 cases selected randomly for one empirical survey did the plaintiff represent himself. See JUDICIAL CONTROLS, supra note 13, at 28,51 . 
other rational individuals, the attorney employed by a litigant as his agent presumably attempts to maximize his own utility. ${ }^{34}$ Because an attorney gains some benefits from discovery that do not accrue to his client, ${ }^{35}$ and particularly because the attorney incurs few of the costs of discovery, ${ }^{36}$ the litigant's employment of an attorney to serve as his agent in litigation creates additional incentives for excessive discovery. ${ }^{37}$

The traditional economic solution to a cost externality is to charge the decisionmaker for the costs that he imposes upon others, thus "internalizing" the externality. ${ }^{38}$ In the case of discovery, the requesting party would be charged for the costs incurred by the responding party in complying with the request. These costs could be estimated by either the responding party or a neutral party. ${ }^{39}$ Unfortunately, both schemes present practical problems.

In a system in which the requesting party was liable for the costs of

34. See Jensen \& Meckling, Theory of the Firm: Managerial Behavior, Agency Costs, and Ownership Structure, 3 J. FIN. ECON. 305, 308 (1976) (agents will advance their own interests when divergent from those of principal). There is a growing literature incorporating rigorous models of the incentives generally facing agents whose efforts cannot be costlessly monitored. See Harris \& Raviv, Some Results on Incentive Contracts with Applications to Education and Employment, Health Insurance, and Law Enforcement, 68 AM. ECON. REV、 20 (1978); Holmström, Moral Hazard and $O b$ servability, 10 BELL J. ECON. 74 (1979); Jensen \& Meckling, supra, at 308-10, 323-25, 328-29; Levmore, Monitors and Freeriders in Commercial and Corporate Settings, 92 YALE L.J. 49 (1982).

35. The benefits from using discovery to establish a reputation as a difficult opponent are greater for the attorney than for the client, leading to more discovery than the client would desire. Such benefits accrue to the attorney whenever someone considers employing him, while the client benefits only upon the (presumably) rarer occasions when someone considers suing him or he considers suing someone.

36. Attorneys' fees are a cost to the client but a benefit to the attorney. The interests of attorney and client in this respect are thus diametrically opposed.

Paying attorneys on an hourly basis further encourages expenditures excessive from the client's viewpoint, since attorneys are thereby encouraged to charge their clients for as many hours of work as possible rather than to complete a given task as rapidly as possible. Of course, it is likely that hourly wages are themselves a response to the problems of monitoring attorneys.

37. The degree to which the interests of attorney and client diverge determines the benefits to the attorney from making decisions counter to his client's interest, and thus the benefits to the client from monitoring his attorney to prevent such behavior. Because monitoring is costly, however, the attorney will produce more legal services, including discovery services, than the client would desire. Litigants will undertake monitoring only when the benefits exceed the costs, and therefore some decisions by attorneys that clients would veto if monitoring were costless will nonetheless be rationally allowed in a world of costly monitoring.

Attorneys paid on a contigency-fee basis, however, have a more direct incentive to maximize the gain to their clients, since their fees increase with increases in the award to their client. Attorneys compensated in this fashion also have an incentive to keep the costs of litigation low since they generally pay those costs themselves. Monitoring is thus less necessary when the attorney is paid a contingency fee.

38. See J. HIRSHLEIFER, supra note 5, at 534-35.

39. To have the requesting party estimate compliance costs is another conceivable alternative. It is, however, likely to be inferior to the other possibilities. The problems of having the requesting party calculate compliance costs are similar to those of having the responding party make the calculation, see infra p. 359, except of course that the requesting party will have an incentive to underestimate such costs. There is, however, the added disadvantage that the requesting party is unlikely to have the best information about the true costs of compliance since it is the responding party who must actually comply. 
responding to his requests, there would be an incentive for the responding party to exaggerate the costs of complying with those requests. ${ }^{40}$ The bargaining position of the replying party would improve as the compliance costs paid by the requesting party increased: An increase in the requesting party's total expected costs of litigation reduces his net gain from litigation and thus makes him more likely to settle on terms favorable to the responding party. ${ }^{41}$ It is therefore probably unwise to allow the responding party to compute the costs of complying with the request. ${ }^{42}$

The most promising alternative is to use a disinterested third party, such as a judge, to determine those costs. Because the responding party has superior information about the subject matter and costs of the discovery request, ${ }^{48}$ however, there will be transaction costs when a third-party monitor attempts to calculate compliance costs. Information about the costs of responding to a particular request must be conveyed to the monitor and, in order to reduce the chances that the responding party will be able to persuade the monitor to adopt an exaggerated estimate, the requesting party must be given an opportunity to contest the responding party's estimate. Such adversarial proceedings are costly.

Transaction costs can also lead to departures from the efficient level of discovery. In some instances, the expected costs of monitoring compliance costs will exceed the expected social benefits from preventing discovery abuse. Society should then allow such requests even though they should be disallowed in the absence of monitoring costs. ${ }^{44}$

40. This inflation of costs could take two forms. First, the responding party might simply exaggerate the number of hours of work actually performed. Second, the responding party might work more hours on a particular request than was truly necessary. The first method of cheating offers a greater reward, since the responding party thereby receives income without having sacrificed any time. The second method of cheating is presumably more difficult to detect, however, since the effort necessary to answer a particular request is presumably more difficult to monitor than the amount of time actually spent by attorneys in answering the request. Cf. infra pp. 366-67 (complete failure to participate in discovery process easier to detect than substantive deficiencies in responses).

41. See infra p. 361 . The purpose of the payment is to prevent the requesting party from making a request unless the benefits of doing so exceed the costs he imposes upon himself and upon his opponent. To achieve this purpose therefore requires only that the requesting party pay the total costs of his requests to someone, not that he pay it to the responding party. Equity, not efficiency, determines who should receive the payment.

42. If the system chosen did require the requesting party to pay the responding party for the latter's compliance costs, a responding party would simply receive more money as the compliance costs paid out by the requesting party increased, obviously creating a further incentive to exaggerate compliance costs.

43. Unless the responding party's information were superior to that of the requesting party, there would generally be no reason to make the request. It is possible, however, that the requesting party might make the request simply to burden his opponent or to determine the facts that the responding party has upon which to base a settlement offer.

44. In addition, there may be cases in which society decides to allow inefficient discovery in order to satisfy distributional concerns. For example, some think it unfair to make a litigant pay to obtain information necessary to redress a wrong that he has suffered. This concern is likely to be particularly acute if the plaintiff is significantly poorer than the defendant. 
Monitoring is therefore a "second-best" solution to the externality problem of discovery. Because of the incentives the responding party has to exaggerate his compliance costs, however, monitoring seems likely to be a better solution to the externality problem than making the requesting party pay the costs estimated by the responding side. ${ }^{45}$

\section{The "Decision-to-Settle" Economic Model of Discovery}

The nature of the incentives for discovery abuse can be analyzed more systematically by using an economic model of a litigant's decision whether to settle a case or proceed to trial. ${ }^{16}$ The model most widely applied in economic analyses of the law defines the net expected gain to the plaintiff from proceeding to trial as his expected return from trial ${ }^{47}$ minus his costs of proceeding to trial. ${ }^{48}$ This total is the minimum settlement offer that the plaintiff will accept: A smaller settlement will place him in a worse position than if he proceeded to trial. ${ }^{49}$

The net expected loss to the defendant from proceeding to trial is the expected judgment plus his costs from proceeding to trial..$^{50}$ This total is the highest amount the defendant will offer: $\mathrm{A}$ higher settlement would make the defendant worse off from settling than from proceeding to trial. If the minimum offer acceptable to the plaintiff is greater than the maximum offer acceptable to the defendant, the parties will fail to settle and thus proceed to trial. ${ }^{51}$ If the minimum offer acceptable to the plaintiff is less than the maximum offer acceptable to the defendant, the parties will settle. ${ }^{32}$

45. The Rules in fact adopt the monitoring solution. See infra pp. 368-70.

46. See Posner, supra note 27, at 417-20. The essentials of this model were set forth in Posner, The Behavior of Administrative Agencies, 1 J. LEGAl STUD. 305, 320-23 (1972). Posner's model is almost entirely anticipated in Note, supra note 27, at 70-71; see also Landes, An Economic Analysis of the Courts, 14 J. L. \& ECON. 61, 101-02 (1971) (model of criminal litigation and outline of civil analog).

47. A litigant proceeding to trial also benefits by saving whatever transaction costs he would incur in reaching a settlement. See Posner, supra note 27, at 418; Note, supra note 27, at 73-74, 90-91.

48. The costs of proceeding to trial include both the fees that the litigant must pay his attorney and the time that the litigant must himself spend in monitoring his attorney, being deposed, and attending the trial.

49. The model generally assumes that the litigants are risk neutral-that is, that a litigant cares only about the average benefits from trial and not about the spread of the outcomes. The effects upon the model of other attitudes toward risk are explored briefly in Gould, The Economics of Legal Conficts, 2 J. LEGAL STUD. 279, 291-93 (1973).

50. The defendant also offsets the savings from avoiding the transaction costs of reaching a settlement against his loss from proceeding to trial. See Posner, supra note 27, at 418; Note, supra note 27, at 73-74, 90-91.

51. See Posner, supra note 27, at 417-18; Note, supra note 27, at 70-71.

52. To reach such a conclusion, one must assume that the litigants bargain rationally-that is, that the litigants will reach some position through bargaining that they both prefer to going to trial if such a position exists.

A party expecting to relitigate the particular issue involved or hoping to signal potential litigants that he is a difficult opponent will also consider such future benefits in his decision. 
The traditional model specifies only the upper and lower bounds of possible settlements, not the particular settlement terms actually reached. This Note expands that model by assuming that an increase in a litigant's expected costs of litigation decreases his net expected benefits from proceeding to trial and thus decreases the magnitude of the settlement offer necessary to induce him to settle. ${ }^{53}$

To apply this model to discovery, ${ }^{54}$ this Note assumes that answering discovery requests increases the expected costs to the responding party of proceeding to trial. ${ }^{\text {Sb }}$ If a discovery request is more costly to answer than to request, ${ }^{88}$ discovery requests will improve the settlement position of the requesting party. The costs of the requesting party will increase less than his opponent's costs, and thus the requesting party's relative settlement postion will improve. ${ }^{57}$ Under this model, then, litigants have an incentive to use harassing discovery requests to maximize the difference between the costs imposed upon their opponents and the costs they incur themselves.

\section{Discovery and the Prisoner's Dilemma}

Since the discovery requests of both litigants contribute to total expenditures on discovery, it is the interaction of the discovery decisions of the two litigants that determines the discovery costs each incurs. Game theory can therefore provide some insight into the likely behavior of litigants with respect to discovery. ${ }^{88}$ In particular, when deciding whether to impose dis-

53. The Note assumes further that, if costs increase for both parties as a result of some event-that is, a discovery request costly both to formulate and to answer-the settlement position of the litigant suffering the greater increase in costs will deteriorate relative to that of his opponent.

54. Priest has applied the economic model of the settlement decision in two contexts outside of its original application, though in neither case to discovery. See Priest, Selective Characteristics of Litigation, 9 J. LEGAL STUD. 399 (1980) (model implies severe difficulty in attempting to infer any particular decision rule from appellate decisions); Priest, The Common Law Process and the Selection of Efficient Rules, 6 J. LEGAL STUD. 65 (1977) (model implies common law will evolve toward efficient rules independent of judges' general decision rules).

55. See supra pp. 353-56.

56. The requesting party also incurs costs in making his request, since he must spend time and money formulating and transmitting his requests. If he hopes to reap any benefits from the request beyond those from harassing his opponent, see supra pp. 356-57, the requesting party must also spend time and money reviewing his opponent's response. In general, however, the costs of making a request are less than the costs of compliance, since requesting information is likely to be less expensive than searching for the raw information and then shaping it into a suitable response.

57. If the effect is sufficiently large, discovery requests may affect whether settlement occurs at all: A plaintiff might be unwilling to settle for some given figure when faced with low litigation costs but willing to settle for the same figure when threatened with high litigation costs from harassing discovery.

58. Game theory is a hybrid of economics and mathematics concerned with the decisionmaking of interdependent actors. The seminal work is $J$. VON NEUMANN \& O. MORGENSTERN, THEORY OF GAMES AND ECONOMIC BEHAVIOR (1944). A more accessible work is M. DAVIS, GAME THEORY: A NON-TECHNICAL INTRODUCTION (1973).

Game theory has been applied to legal issues in a few substantive areas but never to procedural issues. See Note, Games Bargaining: A Proposed Application of the Theory of Games to Collective Bargaining, 65 YALE L. J. 660 (1956) (labor law); Birmingham, Legal and Moral Duty in Game 
covery costs on the other party, a litigant faces the "Prisoner's Dilemma."

Figure 1 illustrates the Prisoner's Dilemma. ${ }^{60}$ There are two parties, Marbury and Madison. Each party can pick either strategy $X$ or strategy $Y$. Each box labeled with a lower-case letter describes the outcome of a particular combination of strategies. (For example, the box labeled " $\mathrm{a}$ " is the outcome when Marbury chooses strategy $X$ and Madison also chooses strategy $X$.) The first number in a box is the resulting benefit to Marbury, and the second number is the resulting benefit to Madison. (For example, the outcome in " $b$ " is that Marbury receives five units of benefits and Madison receives one unit of benefits.)

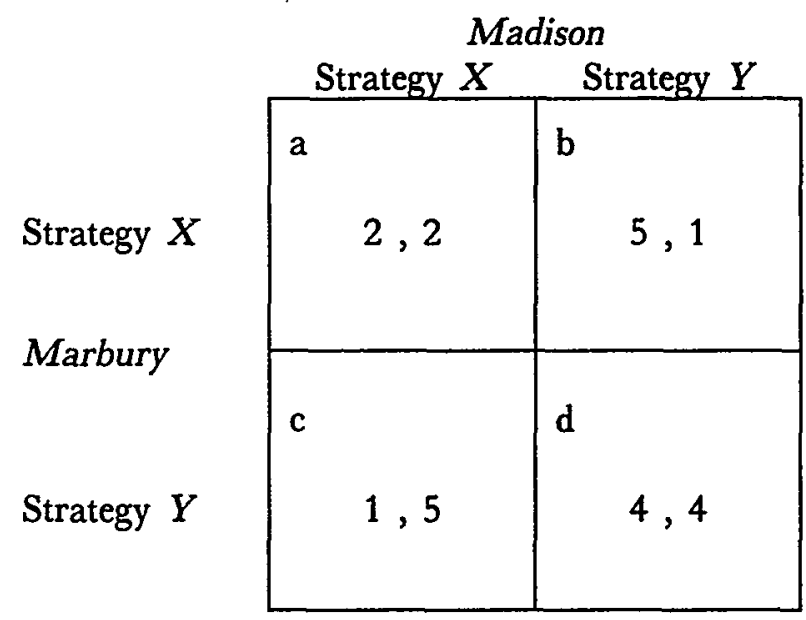

Figure 1: The Prisoner's Dilemma

Two properties define the Prisoner's Dilemma: (i) given either choice of strategy by his opponent, a party does better to choose strategy $X$, and (ii) both parties gain less if both choose strategy $X$ than if both choose strategy $Y{ }^{\mathbf{E l}}$ Under such conditions, a party has a strong incentive to choose

Theory: Common Law Contract and Chinese Analogies, 18 BUfFALo L. REV. 99 (1968-1969) (contracts); Shubik, A Game Theorist Looks at the Antitrust Laws and the Automobile Industry, 8 STAN. L. REV. 594 (1956) (antitrust).

59. Posner has noted that the parties' decisions about litigation expenditures are interdependent. See R. POSNER, ECONOMIC ANALYSIS OF LAW 445-47 (2d. ed. 1977). He does not discuss either the conditions of litigation that make it likely that the parties face the Prisoner's Dilemma or the Prisoner's Dilemma itself.

60. See M. DAVIS, supra note 58, at 93-98; Birmingham, supra note 58, at 103-04. For a review and analysis of the voluminous empirical literature on the Prisoner's Dilemma, see A. RAPOPORT, M. GUYER \& D. GORDON, THE $2 \times 2$ GAME (1976).

61. In general, the Prisoner's Dilemma exists whenever these two conditions are satisfied. The numbers chosen in Figure 1 are otherwise arbitrary.

The Prisoner's Dilemma is most likely to result in the unconstrained outcome when there is only one opportunity for the participants to choose strategies and receive their gains. If the "game" is repeated-as it is in the case of discovery-participants may be able to choose their strategies to 
strategy $X$, since otherwise the opposing party can choose strategy $X$ and gain at the expense of the first party. If both sides choose strategy $X$, however, they will both be in a worse position than if both had chosen strategy $Y$. The result when both sides choose strategy $X$ (outcome "a" in Figure 1) can be termed the "unconstrained" outcome, since it is the likely outcome when the parties do not have their options constrained by a third party. The result when both sides choose strategy $Y$ (outcome "d" in Figure 1) can be called the "benefit-maximizing" outcome, since it is the outcome that maximizes the total gross benefits to the parties from the process. $^{62}$

The rules governing discovery, by allowing a litigant to impose costs upon the opposing side, ${ }^{63}$ place the litigants in a Prisoner's Dilemma. First, given the choice of the opposing side, a litigant gains more favorable settlement terms from making a harassing discovery request than from exercising restraint. ${ }^{64}$ Second, both parties will be worse off if both choose to make such discovery requests than if neither litigant makes such requests. Litigants derive no benefit if both sides conduct harassing discovery imposing equivalent costs: Each litigant's costs will increase by the same amount and thus the relative settlement terms will remain the same. ${ }^{65}$ In fact, each litigant will have incurred costs in having to prepare his own discovery requests and to comply with those of his opponent, and thus will be worse off than if neither side had engaged in harassing discovery. ${ }^{B 6}$

In this way, each potentially harassing pair of discovery requests ${ }^{67}$

increase the likelihood that the benefit-maximizing outcome will occur. For example, a participant might always choose strategy $X$ in a round following his opponent's choice of strategy $X$ and always choose strategy $Y$ in rounds following his opponent's choice of strategy $Y$. The opponent will then find it in his interest to play strategy $Y$ each time and the benefit-maximizing outcome will occur. The incentive for a participant to choose strategy $X$ to benefit at his opponent's expense still remains, however. Furthermore, harassing discovery is not easy to distinguish from legitimate discovery; the opponent may therefore find it difficult to distinguish a legitimate but burdensome request from a request taken in pursuit of a stategy of harassment.

62. In order to obtain this outcome, it may be necessary to adopt costly monitoring mechanisms. Consequently, net benefits are not always maximized simply by achieving this outcome. See infra pp. 368-69.

63. See supra pp. 353-56.

64. The analysis assumes that the total costs of litigation to the responding party increase more rapidly than the costs to the requesting party, and thus that the responding party's relative settlement position will worsen. For the former assumption to hold, the costs of making the request must be less than the cost of responding to the request, which seems likely given the structure of the Rules. See supra note 56. This decrease in the litigant's share of the total costs of litigation leads to an improvement in his relative settlement position. See supra p. 361 .

65. The analysis thus assumes that the litigants have an equal opportunity to harass one another. For a discussion of the effects of unequal harassment opportunities, see infra p. 372.

66. See supra p. 361.

67. It is obviously unnecessary for discovery requests to come in pairs. The analysis treats them as such only for heuristic purposes. The pairing assumption is completely unnecessary when examining discovery as a whole. 
presents the litigants with a Prisoner's Dilemma. Choosing to make a harassing request ("harassment") is equivalent to strategy $X$ in Figure 1, while choosing to refrain from such a request ("restraint") is equivalent to strategy $Y$. Because the costs of complying with discovery requests are additive, a decision to use harassing discovery extensively is equivalent to strategy $X$, while general restraint is equivalent to strategy $Y^{68}$ Thus, the benefit-maximizing outcome is unlikely to occur unless the externalities involved in making discovery requests are controlled in some fashion. ${ }^{69}$

\section{Applying the Model to the Rules}

The rules on discovery mitigate the Prisoner's Dilemma. First, they attempt to internalize some of the costs of discovery. Second, they provide the means for judges to intervene in the discovery process to prevent the unconstrained outcome of the Prisoner's Dilemma. In both cases, they reflect an awareness of the costs of monitoring.

The Rules provide for two modes of judicial intervention. They allow indirect intervention by permitting litigants to make judicially enforceable private agreements concerning discovery in a wide variety of circumstances. ${ }^{70}$ Rule 29 allows litigants to agree upon virtually any changes in discovery procedures; ${ }^{71}$ rule 36 encourages agreements that certain issues

68. Since the magnitude of outcomes involved in discovery as a whole is much greater than that involved in a pair of discovery requests, the incentive to choose strategy $X$ is greater as well. $B u t$ cf. supra note 61 (repeated discovery may reduce Prisoner's Dilemma problems).

69. Expected litigation costs will thus increase for both sides. One effect of harassing discovery is therefore a decrease in the number of lawsuits filed: If litigation is more expensive, fewer people will "consume" litigation. An increase in the expected costs of litigation also lowers the expected net value to a litigant of proceeding to trial. Such a change makes settlement more attractive. See Posner, supra note 27 , at 418 .

Society and the litigants benefit from an increase in the settlement rate to the extent that threatened expenditures of resources substitute for real expenditures, since with threatened expenditures neither side actually sacrifices the resources which would have been expended if the threats had been carried out. If preventing the expenditure of real resources on litigation were the only consideration, society would simply prohibit litigation altogether. There are obviously some benefits from litigation, however. These benefits may in many cases outweigh its costs.

As long as the threatened discovery expenditures would, if actually carried out, result in a net savings to society, there would be a net gain to society from discovery foregone in favor of settlement. Because of the externality problem, however, not every threatened expenditure will be socially efficient. See supra p. 357. It is therefore impossible to know whether the savings from discovery foregone because of the threat of harassing discovery is in fact a net gain to society.

70. One court has even upheld a contractual provision limiting discovery entered into before the claims of the case arose. See Elliot-McGowan Prods., Inc. v. Republic Prods., 145 F. Supp. 48, 50 (S.D.N.Y. 1956). This decision was criticized in Developments in the Law-Discovery, 74 HARV. L. REV. 940, 979-80 (1961).

71. Rule 29 reads in part: "Unless the court orders otherwise, the parties may by written stipulation . . . modify the procedures provided by these rules for [the] methods of discovery . . .." It limits modifications of depositions to those affecting the notice, time, place, and "manner" of the deposition or the person before whom it is taken. Rule 29 also prohibits the litigants from agreeing to extend the time within which they may respond to interrogatories, requests for documents, and requests for admission without the approval of the court.

Stipulations regarding changes in discovery procedures are "common practice." See FED. R. CIV. P. 
are undisputed by providing sanctions against a litigant unreasonably recalcitrant in making such agreements. ${ }^{72}$ Rule 26(c) allows direct intervention $^{73}$ by permitting a judge, upon the motion of a party, ${ }^{74}$ to issue a protective order limiting or prohibiting discovery requests in a wide variety of ways. ${ }^{75}$

\section{A. Mitigating the Prisoner's Dilemma by Internalizing Costs}

The Prisoner's Dilemma stems from the costs that one litigant can impose upon the other ${ }^{76}$ By providing for the imposition of monetary costs in some cases in which a party has imposed unreasonable costs upon his opponent, the Rules seek to mitigate this externalization of costs. ${ }^{77}$ By

29 advisory committee note. One example of a procedure generally conducted by stipulation is the medical examination otherwise governed by rule 35 . See Liechty v. Terrill Trucking Co., 53 F.R.D. 590, 591 (E.D. Tenn. 1971) (examinations customarily accomplished by stipulation with rule 35 as compulsory "sanction" encouraging stipulations); W. GLASER, PRETRIAL DISCOVERY AND THE AD. VERSARY SYSTEA 55 (1968). Another is the allocation of transcription costs of depositions. See id. at 169.

72. The Rules encourage such agreements by requiring the responding party to make a reasonable effort to determine the veracity of the request before denying it and by backing the requirement with significant sanctions. See supra note 16.

73. Rule 30(d), which governs limiting or terminating depositions in progress, also allows direct judicial intervention. See FED. R. CIV. P. 30(d). The discovery conference, see FED. R. CIV. P. 26(I), is a mixture of direct and indirect interventions for use in broad disputes. See FED. R. CIV. P. 26(f) advisory committee note ("relatively narrow discovery dispute[s]" should be resolved by means other than discovery conference). The resulting intervention is an order issuing from a discovery conference limiting the general shape of discovery, rather than individual discovery requests, and is thus partly indirect. The judge's role is conceived as facilitative rather than purely adjudicative. See FED. R. CIV. P. 26(I) advisory committee note (referring to "assistance" of court). This facilitative role is another indicator of the unusual status of the discovery conference in the array of interventions provided by the Rules. $C f$. MANUAL FOR COMPLEX LiTIGATION $\S \S 1.50-1.70,1.95,2.20-2.70,3.11-3.21$ (5th ed. 1982) (subjects of series of pretrial conferences concerned with discovery matters). The judge may order a discovery conference without a motion from the parties, however, see FED. R. CIV. P. 26(f), so the intervention is not purely indirect.

For a comparison of the desirability of direct and indirect intervention, see infra pp. 368-69.

74. Generally the movant is the responding party. The requesting party may also seek such an order, however. See Central Hide \& Rendering Co. v. B-M-K Corp., 19 F.R.D. 296 (D. Del. 1956) (exclusion of nonofficer of responding corporation from deposition in patent case).

75. The judge has broad power in shaping the protective order. The order may limit or prohibit entirely the discovery of the subject matter requested, or it may modify or change the method or procedure of discovery to be employed. See FED. R. CIV. P. 26(c). For examples of cases employing protective orders, see Zwack v. Kraus Bros. \& Co., 237 F.2d 255, 260 (2d Cir. 1956) (limiting transmission to Hungary of deposition discussing bribery of Hungarian Communist Party officials by individual still in Hungary); Colonial Capital Co. v. General Motors Corp., 29 F.R.D. 514, 518 (D. Conn. 1961) (specifying written questions for questioning of nearly deaf person); Timblo v. Rhode Island Ins. Co., 16 F.R.D. 563 (S.D.N.Y. 1954) (written questions for plaintiff in Portuguese India).

76. See supra pp. 353-56. These costs allow the requesting party to improve his settlement position by threatening to increase the responding party's litigation costs. Along with the relative costs of composing and answering a discovery request, see supra note 56 , this improvement in relative settlement position leads to the Prisoner's Dilemma. See supra pp. 363-64.

77. The court will compensate the harassed party for the "reasonable expenses, including attorney's fees," incurred as a result of the other party's harassing action. See FED. R. CIV. P. 37(b), (d). The typical litigant seeks compensation only for his attorney's fees and not for the time or mental anxiety he incurs. Sce cases cited infra notes $82,84$.

Rules 37 (b) and 37 (d) also provide for a variety of nonmonetary sanctions to deter discovery abuse, 
limiting the internalization of monetary costs to situations either in which the costs of transferring information to the monitoring judge are inherently low or in which the party seeking the internalization can meet a significant burden of persuasion, the Rules attempt to ensure that the benefits of the internalization exceed the transaction costs of transferring the relevant information to a monitor.

The Rules seek to internalize the costs of complying with discovery requests in several situations. When the responding party fails completely to participate in the discovery process, courts hold the responding party liable for the costs thus imposed upon the requesting party. Because the costs of detecting such actions are low, this assignment of costs is socially efficient. Behavior in this category includes failing to appear at a scheduled deposition $^{78}$ and failing to provide any answers at all to an interrogatory. ${ }^{78}$ An attempt to force the responding party to gather information obviously available at no higher cost to the requesting party involves similarly low monitoring costs, and thus courts also hold the responding party liable for these costs. ${ }^{80}$

When the attempt by one litigant to impose costs upon the other is less obvious but still sufficiently clear that a litigant can meet a burden of persuasion imposed upon him, courts also hold the responding party liable for the resulting costs. ${ }^{81}$ Behavior in this category includes unreasonably

such as dismissing the case, FED. R. CIV. P. 37(b)(2)(C), or prohibiting the introduction into evidence by the responding party of material which should have been provided to the requesting party, see FED. R. CIV. P. 37(b)(2)(B), 37(d). Because these sanctions are qualitative, they can be related only roughly to the actual costs imposed upon the opposing side. They are nonetheless an indirect way of imposing at least some costs upon a litigant attempting to use the discovery process to impose costs upon his opponent.

78. Simple appearance at a deposition is sufficient to prevent the imposition of rule 37(d) sanctions even if the deposition is unproductive. See SEC v. American Beryllium \& Oil Corp., 303 F. Supp. 912, 920 (S.D.N.Y. 1969) (deponent claimed right to avoid self-incrimination and recent dismissal of his attorney). There are a few situations where the behavior of responding party is so egregious that rule 37 (d) sanctions will issue even when the deponent appears. See Brady v. Hearst Corp., 281 F. Supp. 637, 642-43 (D. Mass. 1968) (deponent "reduced to a shambles" attempts to take deposition with behavior "border[ing] on the ludicrous").

79. In the case of interrogatories, "anything less than a serious or total failure to respond" is protection against 37(d) sanctions. See Halverson v. Campbell Soup Co., 374 F.2d 810, 812 n.2 (7th Cir. 1967). For examples of behavior sufficiently unaccommodating to allow the imposition of sanctions, see Addington v. Mid-American Lines, 77 F.R.D. 750, 751 (W.D. Mo. 1978) (responding party neither answered nor objected to interrogatories, nor did he request additional time to answer or object to them); Allied Artists Pictures Corp. v. Giroux, 50 F.R.D. 151 (S.D.N.Y. 1970) (party failed to answer within extended period allowed and did not sign interrogatories finally presented).

80. Parties need not answer interrogatories that require research that the requesting party could perform equally or more cheaply. See Reynolds v. Southern Ry., 45 F.R.D. 526, 528 (N.D. Ga. 1968) (measurements at scene of accident); United States v. 216 Bottles, More or Less, Etc., 36 F.R.D. 695, 702 (E.D.N.Y. 1965) ("outside data and citations to literature"); Needles v. F.W. Woolworth Co., 13 F.R.D. 460, 461 (E.D. Pa. 1952) (weather at time of accident).

81. For an unusual example of such a situation, see Robbins v. Abrams, 79 F.R.D. 600,603 (S.D.N.Y. 1978) (defendant refusing to disclose precise location of mother-in-law somewhere in Europe must produce her or pay plaintiff's costs of deposing her in Europe). 


\section{Discovery Abuse}

failing to admit an issue later proved true ${ }^{82}$ failing to obey the order stemming from a rule $26(f)$ discovery conference, ${ }^{83}$ and failing to answer interrogatories to the best of one's ability with the information within one's control. ${ }^{84} \mathrm{~A}$ more general provision of the Rules makes the losing litigant at any hearing on the legitimacy of a discovery request liable for the costs that he has imposed upon the opposing side, unless he can demonstrate to the court that his action was substantially justified. ${ }^{85}$

Finally, two provisions in the Rules attempt to internalize the costs of discovery requests ex ante. Rule 26(b)(4), which governs discovery of information possessed by the opponent's experts, contains elaborate awardof-fee provisions to ensure that the requesting party does not use discovery to acquire at low cost information that may have been quite costly for his opponent to obtain. ${ }^{86}$ Rule 33(c) allows a litigant to answer an interrogatory by providing the requesting party with the documents containing the information sought, as long as the costs to the requesting party of obtaining the desired information are no higher than they would be for the responding party. ${ }^{87}$

82. See, e.g., Bradshaw v. Thompson, 454 F.2d 75, 81 (6th Cir.), cert. denied, 409 U.S. 878 (1972); United States ex rel. Westinghouse Elec. Supply Co. v. National Sur. Corp., 25 F.R.D. 249, 251 (E.D. Pa. 1960); Akins v. McKnight, 13 F.R.D. 9, 11 (N.D. Ohio 1952). But see Security-First Nat'l Bank v. Lutz, 297 F.2d 159, 165-66 (9th Cir. 1961) (no sanctions where defendant "flabbergasted" at finding by his own expert that contested signature was his); Garrison v. Warner Bros. Pictures, Inc., 226 F.2d 354, 356 (9th Cir. 1955) ("honest and concerted effort" sufficient), cert. denied, 350 U.S. 968 (1956).

83. FED. R. CIV. P. 37(b)(2); cf. Transamerica Corp. v. Transamerica Bancgrowth Corp., 627 F.2d 963 (9th Cir. 1980) (default judgment sanction for failure to comply with local rule requiring good-faith participation in pretrial conference treating discovery).

84. See Surg-o-Flex of America, Inc. v. Bergen Brunswig Co., 76 F.R.D. 654, 655 (D. Conn. 1977) (document requests and interrogatories); White v. Beloginis, 53 F.R.D. 480 (S.D.N.Y. 1971).

85. See FED. R. CIV. P. 37(b). For cases involving the award of fees in connection with rule 37(b), see National Lawyers Guild v. Attorney Gen., 94 F.R.D. 616, 621 (S.D.N.Y. 1982); Damiani v. Rhode Island Hosp., 93 F.R.D. 848, 852-53 (D.R.I. 1982). But see Wood v. Breier, 66 F.R.D. 8, 14 (E.D. Wis. 1975) (seeking protective order substantially justified in claims of executive privilege since case-by-case decisions are required).

These provisions also act as sanctions against those who attempt to thwart judicial efforts to resolve the Prisoner's Dilemma efficiently. Since mitigating the externality problem in turn reduces the inefficiency stemming from the unconstrained outcome of the Prisoner's Dilemma, the award of fees to internalize costs penalizes a litigant for exacerbating the Prisoner's Dilemma.

86. See FED. R. CIV. P. 26(b)(4)(C). For examples of cases dividing the costs of shared experts between the litigants, see Keith v. Van Dorn Plastic Mach. Co., 86 F.R.D. 458 (E.D. Pa. 1980) (requesting party must pay expert reasonable fee for deposition); Herbst v. International Tel. \& Tel., 65 F.R.D. 528 (D. Conn. 1975) (costs of retaining expert to be shared and costs of deposing expert to be paid by requesting party). The court did not impose fee-sharing in Pearl Brewing Co. v. Joseph Schlitz Brewing Co., 415 F. Supp. 1122, 1138 (S.D. Tex. 1976) (requesting party sought information, not to avoid compensating experts, but to discover precise assumptions behind sophisticated computer model to be used by expert witness).

87. See Technitrol, Inc. v. Digital Equip. Corp., 62 F.R.D. 91, 93 (N.D. Ill. 1973) ("[B]oth parties are in an equal position to sort through the material.").

The option to respond with documents rather than with the processed information allows the responding party to place the compliance costs upon the requesting party, while the requirement that the resulting search be no more costly for the requesting party than for the responding party avoids 


\section{B. Mitigating the Prisoner's Dilemma Through Judicial Intervention}

The rules governing discovery also attempt to mitigate the Prisoner's Dilemma by allowing judicial participation in the discovery process.

\section{Choosing the Mode of Intervention}

A third-party monitor can attempt to resolve the Prisoner's Dilemma and promote the benefit-maximizing outcome either by requiring that both litigants pursue a strategy of restraint or by standing ready to enforce an agreement by the litigants to pursue such a strategy ${ }^{88}$ If the monitor has adequate sanctions to enforce the more interventionist solution, this approach will lead to the benefit-maximizing outcome. ${ }^{39}$ As long as the costs of intervention, including the costs of transferring the necessary information to the monitor and of the occasional use of sanctions, are less than the resources saved by pursuing restrained discovery, society will benefit from direct intervention.

The less interventionist solution, in which the monitor merely enforces a private agreement of the parties, ${ }^{90}$ will occur if the monitor has adequate sanctions $\mathrm{s}^{91}$ available to enforce that agreement and both parties gain more from moving from the unconstrained outcome toward the benefitmaximizing outcome than they expend in reaching an accord. ${ }^{92}$ If the net

creating an incentive for the responding party to exaggerate his costs of response. See supra p. 359.

The responding party cannot simply state that the information requested is somewhere in the documents offered for inspection. See Flour Mills of America, Inc. v. Pace, 75 F.R.D. 676, 680-81 (E.D. Okla. 1977); Budget Rent-A-Car, Inc. v. Hertz Corp., 55 F.R.D. 354, 357 (W.D. Mo. 1972). This rule is consistent with efficiency notions, since it is unlikely that such a cursory specification is all that the responding party could accomplish at lower cost than the requesting party.

In order to discourage the creation of perverse incentives, courts will not shift the financial burden of discovery to the requesting party when the costliness of response is due to the responding party's choice of an awkward indexing scheme. See Alliance to End Repression v. Rochford, 75 F.R.D. 441, 447 (N.D. Ill. 1977) (internal government memoranda not stored in any organized file); Kozlowski v. Sears, Roebuck \& Co., 73 F.R.D. 73 (D. Mass. 1976) (no index of product complaints by product).

88. Cf. MANUAL FOR COMPLEX LITIGATION, supra note $73, \S 1.10$ (essence of program is exercise of judicial control plus positive plan for discovery).

89. "Adequate" sanctions in the context of direct intervention are those which, for both litigants, make the final expected rewards from choosing a harassment strategy less than the (unchanged) rewards from restraint, no matter which choice is made by the opposing litigant. Both sides will then choose restraint, resulting in the benefit-maximizing outcome.

90. This private agreement is closely analogous to a conventional contract, although the concept of "damages" for a breach is rather difficult to apply. The Prisoner's Dilemma analysis has in fact been applied to contract law, but with little attention to information costs. See Birmingham, supra note 58, at $105-06$.

91. In the context of indirect intervention, sanctions are "adequate" if the punishment for the party breaking the agreement would cost him more than the benefits to him from breaking that agreement. Both parties will then adhere to the agreement of restraint, producing the benefit-maximizing outcome. This Note does not consider when breach of the agreement might be desirable. For a discussion of efficient breach in the context of conventional contracts, see R. POSNER, supra note 59, at 88 89.

92. The participation of a neutral third party may lower the transaction costs of making such an agreement. The discovery conference, see supra note 73 , is an example of such participation in the 
gain to the parties from a private agreement exceeds the costs to society of enforcing that agreement, including the cost of transferring the necessary information to the monitor, then society will benefit from indirect intervention.

The more desirable policy is that which maximizes the differences between the benefits and the costs of intervention. In general, the information necessary for a system of private agreements is less costly to obtain. First, indirect intervention requires the transfer of information to the monitor only when one party accuses the other of breaking the agreement. Direct intervention, in contrast, routinely requires the transfer of information to the monitor, since the monitor must provide guidelines without any guidance from provisions negotiated by the parties. Second, in a system of private agreements, the initial agreements are available to assist the monitor in designing an efficient solution, and the agreements were formulated when the interests of the parties were aligned. ${ }^{93}$ In contrast, parties operating under direct intervention made no initial agreement, and so the only information available to the monitor is that generated in the context of the intervention, when the interests of the parties are opposed. To the degree that the true interests of the parties can be more reliably inferred when that information is generated by parties with aligned rather than opposed interests, obtaining reliable information will be less expensive in a system of indirect intervention.

If both systems of intervention produced the same benefits, indirect intervention would always be more efficient because of its lower costs. In some situations, however, the litigants will be unable to structure their discovery so that both will benefit. In those situations, no private agreement will ensue and therefore a system of conditional intervention will result in no intervention at all and thus produce no benefits. Direct intervention is then the only method capable of achieving the gains from the benefit-maximizing resolution of the Prisoner's Dilemma.

\section{The Rules and Intervention}

By allowing a broad scope for private agreement between the parties and by limiting direct intervention to instances in which the litigant seeking intervention can persuasively show that such intervention is desirable, the Rules encourage the most efficient solution to the Prisoner's Dilemma. The less costly indirect intervention is the norm, but direct intervention can occur if information-transfer costs are low enough for the responding

Rules.

93. If the agreement was not initially in the interests of both parties, they would not both have consented to a voluntary agreement. 
party to meet a significant burden of persuasion. ${ }^{94}$ This requirement limits direct intervention to instances in which the benefits of such intervention significantly exceed the costs to the party seeking intervention. ${ }^{95}$

\section{The Evolution of the Rules in Light of Historical Trends in Federal Causes of Action}

Complex cases and cases involving the poor have become more frequent since the adoption of the Federal Rules of Civil Procedure. In such cases, there are great incentives to engage in harassing discovery. The Rules have correspondingly become more concerned with the efficient resolution of the Prisoner's Dilemma.

\section{A. The Implications of Some Trends in the Nature of Federal Cases}

Since the adoption of the Federal Rules of Civil Procedure-and in part because of their adoption-both the complexity of problems potentially subject to regulation through litigation ${ }^{98}$ and the avenues of litigation open to the poor ${ }^{97}$ have expanded greatly. The Rules have for the

94. The party seeking direct intervention must show "good cause" before the order will issue. See, e.g., Essex Wire Corp. v. Eastern Elec. Sales Co., 48 F.R.D. 308, 310 (E.D. Pa. 1969) (good cause shown where "great competitive disadvantage" would result from disclosure of contract terms); Frost v. Williams, 46 F.R.D. 484 (D. Md. 1969) (protective order granted against form interrogatory which asked, inter alia, whether it was snowing at time of accident, which occurred in July); see also supra pp. 364-65 (specific rules governing direct and indirect intervention).

95. See, e.g., Isaac v. Shell Oil Co., 83 F.R.D. 428, 432 (E.D. Mich. 1979) (plaintiff lacked reasonable grounds for requesting information and costs of response estimated at \$17,000); Struthers Scientific \& Int'l Corp. v. General Foods Corp., 45 F.R.D. 375, 379 (S.D. Tex. 1968) (value of requested material "far outweighed" costs of response); Rosanna Knitted Sportswear, Inc. v. Lass O'Scotland, Lid., 13 F.R.D. 325, 326 (S.D.N.Y. 1952) ("harassment" to demand that responding party move all files, books, and records to office of requesting party's attorney).

Since information on what will occur at a deposition is difficult to obtain before the deposition, courts will generally refuse to grant protective orders against depositions until a particular question is actually raised. See Salter v. Upjohn Co., 593 F.2d 649, 651 (5th Cir. 1979) ("very unusual" to prohibit taking of deposition altogether).

One might view this general burden of persuasion that the party requesting intervention must meet as a substitute for payment of the information-transfer costs he imposes upon society: The party who sets into motion the costly machinery of intervention must "pay" a premium for doing so in the form of the extra effort necessary to meet the burden of persuasion. If the responding party did not somehow pay for the costs incurred by the judge and the requesting party from participating in the information-transfer process set into motion by the responding party's request for a protective order, he would seek intervention more often than is socially efficient, another example of an externality in the discovery process.

96. This trend has resulted largely from the actions of Congress in allowing various private causes of action for wrongs once exclusively public and in seeking to control through legislation (with its resulting litigation) such once-unregulated areas as apportionment, environmental quality, and racial discrimination.

97. Causes of action based upon the Civil Rights Act of 1964, Pub. L. No. 88-352, 78 Stat. 241 (codified at scattered sections of 42 U.S.C.), and the general cause of action based upon civil rights violations, 42 U.S.C. $\S 1983$, have allowed a significant expansion of the legal rights of the poor. Between 1968 and 1972, the number of civil rights cases in the federal district courts increased $300 \%$, and doubled again between 1972 and 1980. See Clark, Adjudication to Administration: A Statistical 
most part evolved to meet this need. ${ }^{08}$

Complex litigation exacerbates the Prisoner's Dilemma in discovery for two reasons. First, because a complicated case by definition offers the possibility of more information exchange between the litigants, the number and scope of potential discovery requests increases ${ }^{\text {9日 }}$ and thus so does the incentive to choose a strategy of harassing discovery. ${ }^{100}$ Second, complicated cases often involve litigants with substantial resources to commit to the litigation. Such litigants are better able to bear the costs inevitably involved in making harassing requests and are thus more likely to make such requests. ${ }^{101}$ Intervention in complex cases thus becomes particularly desirable.

The changes in both the substantive rights and the procedural options available to less wealthy litigants have increased the opportunity for poor plaintiffs to bring suit. ${ }^{102}$ Because a poor litigant normally suffers more from the loss of a dollar of income than a wealthy litigant, ${ }^{103}$ poor parties

Analysis of Federal District Courts in the Twentieth Century, 55 S. CAL. L. REv. 65, 141, 146 (1981).

The class action, by allowing the vindication of several claims for the cost of a single attorney's fee, see Developments in the Law-Class Actions, 89 HARV. L. REV. 1319, 1355-56 (1976), increases the chances that actions by the poor will actually be brought. Similarly, making a losing defendant in a civil rights case pay the plaintifT's attorney's fees, see 42 U.S.C. $\$ 1988$ (1976), has the same effect. A majority of the class actions brought before 1976 were civil rights claims. See Developments in the Law-Class Actions, supra, at 1325 n.30 (1976).

98. Changes in the Rules have not been the only procedural response to the increase in complex litigation. See generally MANUAL FOR COMPLEX LITIGATION, supra note 73 (elaborate specification of procedures for use in complex litigation).

99. It is probably not coincidental that a case often cited as an example of the dangers of liberal discovery provisions, Ferguson v. Ford Motor Co., 92 F. Supp. 868 (S.D.N.Y. 1950), was a complicated antitrust and patent infringement case. For some idea of the extraordinary scope of a party's activities subject to discovery in a large antitrust suit, see the list of documents requested in United States v. IBM, 76 F.R.D. 97, 100-09 (S.D.N.Y. 1977).

100. As the potential for harassment increases, the magnitude of payoffs in the Prisoner's Dilemma also increases, making restraint even riskier for a litigant and thus making mutual harassment both more likely and costlier for society.

101. Where a complicated case involves two parties with substantial resources, the Prisoner's Dilemma is therefore especially acute. A large antitrust suit brought by the government satisfies these criteria. The government antitrust suit against IBM, which was eventually dropped, provides an idea of the range of questions which may arise in the course of such a case. See, e.g., United States v. IBM, 66 F.R.D. 180 (S.D.N.Y. 1974) (denying motion to limit scope of subject matter of depositions); 70 F.R.D. 700 (S.D.N.Y. 1976) (denying protective order to nonparty computer trade association); 453 F. Supp. 194 (S.D.N.Y. 1977) (denying motion for predeposition protective order against already-asked questions); 76 F.R.D. 97 (S.D.N.Y. 1977) (defendant ordered to produce documents); 83 F.R.D. 92 (S.D.N.Y. 1979) (defendant's accounting firm ordered to produce documents).

Since the court may require defendants to pay the plaintiff's attorney's fees in a successful private antitrust action, 15 U.S.C. $\$ 15$ (1976), antitrust actions impose no costs upon a prevailing plaintiff who has adopted a strategy of harassing discovery.

102. See supra note 97 .

103. If each individual values a given income equally and if the additional value each derives from an additional dollar of income decreases as the level of income increases, poor individuals will value an additional dollar of income more highly than wealthy individuals. It is conceivable, however, that wealthy litigants value income more highly than poorer litigants; one can argue that wealthy parties become wealthy at least in part because they value income more highly than others. 
will suffer disproportionately from an exchange of harassing discovery requests. If the poor litigant makes a harassing request, his loss from his outlays will be greater than the loss the wealthy party incurs in making his own request. If the poor litigant receives a harassing request, his loss from the resulting outlays will be greater than the loss the wealthy party suffers from his response to the poor party's request. If society wishes to redistribute utility from the wealthy to the poor, then judges should be more willing to intervene when a wealthy litigant makes a request of a poor litigant than in other situations. ${ }^{104}$

In some situations in which the plaintiff is relatively poor, the discovery opportunities of the plaintiff are much more extensive than those of the wealthier defendant. ${ }^{105}$ Since the defendant therefore cannot threaten retaliatory discovery, the plaintiff has a particularly strong incentive to employ harassing discovery. ${ }^{106}$ Judicial intervention is thus likely to be especially desirable. ${ }^{107}$

\section{B. Amendments to the Discovery Provisions of the Rules}

Changes in the discovery provisions since 1970 have in fact responded to the increased need for judicial intervention to resolve the Prisoner's Dilemma created by the increase in cases involving poor litigants and in complex cases. The 1970 amendments to the Rules, the first significant revision of the discovery provisions, substantially increased the ability of judges to resolve the Prisoner's Dilemma efficiently. ${ }^{108}$ These amendments

104. One fee-award provision in the Rules explicitly allows distributional concerns to affect the decision. See FED. R. CIV. P. 26(b)(4)(C) (payments to experts not required if "manifest injustice would result"); FED. R. GIV. P. 26(b) advisory committce note (above qualification intended to apply to indigent litigants).

105. Suits involving institution-wide reforms are a good example of situations in which the plaintiff has greater discovery opportunities. See, e.g., Weahkee v. Norton, 621 F.2d 1080, 1082 (10th Cir. 1980) (discrimination suit by employee); Alliance to End Repression v. Rochford, 75 F.R.D. 441, 444-45 (N.D. Ill. 1977) (civil rights claim against governmental surveillance). Class actions under rule $10 \mathrm{~b}-5$ of the Securities Exchange Act of 1934 present a similar situation. See Blue Chip Stamps v. Manor Drug Stores, 421 U.S. 723, 741 (1975) (extensive discovery involving defendant's officers and business documents a common occurrence in such suits).

106. In terms of the model of the Prisoner's Dilemma, the defendant's choice is effectively constrained to a "restraint" strategy while the plaintiff's is not. Harassment is then clearly the desirable choice for the plaintiff. See supra pp. 362-63.

107. Allowing harassing discovery in such instances redistributes utility from the party with fewer opportunities for harassment to the party with more such opportunities. It should be noted that the party with the greater opportunity to conduct harassing discovery is generally not the party with the greater opportunity to commit resources to litigation. The analysis of the net effect of harassing discovery upon distribution is thus indeterminate. The import of the analysis for discovery abuse is clear, however, since both asymmetry in resources available to commit to litigation and in opportunities to conduct harassing discovery make abuse more likely.

108. Although some changes in the Rules since their adoption have reduced the amount of mandatory judicial intervention, these changes preserve the option of intervention if one of the litigants requests it. For example, the 1970 amendments reduced the amount of required judicial intervention by abolishing mandatory judicial approval of document requests, see FED. R. CIV. P. 34 
expanded the forms of discovery within the scope of private agreements under rule $29^{109}$ and resolved ambiguities in rule 36 in favor of a broad scope for requests for admissions. ${ }^{110}$ Both changes encourage indirect interventions. ${ }^{111}$ The amendments also specifically added the prevention of "undue burden or expense" to the justifications for the issuance of a rule 26(c) protective order-exactly the criterion necessary to allow intervention to prevent harassing requests. By lowering the standard for shifting the costs of both parties in contesting discovery requests to the losing party, ${ }^{112}$ these amendments also reduced the externality problem that generates the Prisoner's Dilemma. The addition of rule 33(c) reduced the degree to which the requesting party could impose costs upon the responding party through interrogatories, ${ }^{113}$ while the addition of rule $26(b)(4)$, governing the award of fees when an opposing expert's information was the object of a discovery request, ${ }^{114}$ also served to mitigate the externality problem. The 1980 amendments were less extensive, but they added the discovery conference to the interventions available to the judge ${ }^{115}$ and refined the rules on interrogatories ${ }^{116}$ and document requests ${ }^{117}$ in a manner consistent with the efforts to reduce the externality problem.

\section{Conclusion}

Considered in their entirety, the Rules appear to provide judges with the potential to mitigate the Prisoner's Dilemma in discovery and also

advisory committee note, while leaving open the possibility for the parties to contest the propriety of such requests by seeking direct intervention under rules $26(\mathrm{c})$ and 37 (a).

109. Rule 29, which had originally provided for private agreements only when depositions were involved, was expanded in 1970 to include all other methods of discovery. See FED. R. CIV. P. 29 advisory committee note.

110. See Shakman v. Democratic Org., 481 F. Supp. 1315, 1346 n.35 (N.D. Ill. 1979) (admissions binding); FED. R. CIV. P. 36(a) advisory committee note (request may be of fact or of law, and admissions are binding).

111. See supra pp. 364-65.

112. The standard in rule 37(a) sanctions was changed from awarding costs only if the opposition was "without substantial justification" to awarding costs unless opposition was "substantially justified." See FED. R. CIV. P. 37(a)(4) advisory committee note (change in language "intended to encourage judges to be more alert to abuses"). The 1970 amendments added a similar standard for allowing the award of fees to rule $37(\mathrm{~b})$ and to rule $37(\mathrm{~d})$.

113. See supra p. 367.

114. See id.

115. See supra note 73 .

116. The 1980 amendment to rule 33(c) emphasized the duty of the responding party to present his records in a form as accessible to the requesting party as to himself. See FED. R. CIV. P. 33(c) advisory committee note. This duty prevents the responding party from imposing higher costs upon his opponent than those necessary in any event to obtain the requested information, and thus helps to minimize the total social expenditure on discovery.

117. The 1980 amendment to rule 34(b) specified that the records presented by the responding party must be organized as they were "in the usual course of business." See FED. R. CIV. P 34(b) advisory committec note. This clarification sought to prevent the responding party from imposing excessive costs upon the requesting party by forcing the latter to sort through deliberately mixed-up documents. Id. 
appear to have responded over time to the increasing need to do so. Whether judges have in fact employed the full potential of the Rules in resolving the Prisoner's Dilemma efficiently is a more difficult question. ${ }^{118}$ The most significant failure of judges to reduce the problems of the Prisoner's Dilemma is probably their reluctance to impose the expenses of the party prevailing at a discovery hearing upon the losing party. ${ }^{119}$ Nevertheless, the 1970 amendments, designed to increase the frequency of such awards, ${ }^{120}$ may have been a step in that direction. ${ }^{121}$ Judges remain unwilling to impose sanctions for failure to comply with discovery requests, ${ }^{122}$ another method of limiting the imposition of costs upon one's opponent. The hesitation of judges to issue protective orders is less often lamented but no less prevalent. ${ }^{123}$ Judicial recognition of the dangers of complex litigation ${ }^{124}$ and of the disadvantages faced by poorer litigants has been widespread, ${ }^{125}$ though no court seems to have acknowledged that a poor litigant might abuse a superior opportunity to conduct discovery. ${ }^{\mathbf{1 2 6}}$ The several rounds of amendments to the discovery provisions of the Rules also imply that their drafters believe judges have been less than completely successful in whatever efforts judges have made. ${ }^{\mathbf{1 2 7}}$

A number of further reforms to the rules and case law would be appropriate in increasing judicial effectiveness in mitigating the Prisoner's Dilemma. First, the Rules should be amended to require the losing party at a hearing on the legitimacy of a discovery request to pay the costs of the prevailing party. ${ }^{128}$ Second, judges should require the party requesting ju-

118. While it is tempting simply to suggest more judicial attention to these problems, it is crucial to note that judges labor under demanding caseloads that show no sign of diminishing. The suggestions of this Note therefore attempt to concentrate upon changes that might yield improvements in the efficiency of the discovery process at relatively little cost in judicial time.

119. See C. Ellington, A STUdy OF SANCTions For Discovery Abuse 46-47, 74-76 (1979).

Judges are more willing to award costs when they are also imposing other sanctions. See id. at 49.

120. See FED. R. CIV. P. 37(b) advisory committee note (burden placed on "disobedient party to avoid expenses by showing that his failure [to comply with order to produce discovery] is justified").

121. See C. ElLINGTON, supra note 119 , at 76 n.30.

122. See id. at 63-64, 69-70; W. GLASER, supra note 71, at 154-56.

123. See W. GLASER, supra note 71, at 141-42.

124. See Dolgow v. Anderson, 53 F.R.D. 661, 664 (E.D.N.Y. 1971) (shareholder derivative suit in which court noted that duty to supervise discovery proceedings is of special significance in large and complex cases); Philadelphia Hous. Auth. v. American Radiator \& Standard Sanitary Corp., 50 F.R.D. 13, 19 (E.D. Pa. 1970) (discovery sanctions particularly appropriate in complex antitrust litigation). But see United States v. IBM, 66 F.R.D. 186, 189 (S.D.N.Y. 1974) (burden of responding to requests should be considered less important in view of "size and significance" of case involved).

125. See, e.g., Haymes v. Smith, 73 F.R.D. 572, 574-75 (W.D.N.Y. 1976) (defendant to pay deposition expenses of indigent plaintiff prisoner represented by Legai Assistance Corporation); Terry v. Modern Woodmen of America, 57 F.R.D. 141, 144 (W.D. Mo. 1972) (defendant "most able to bear" expense of plaintiff's trip for his deposition).

126. See supra p. 372.

127. Some amendments have been explicitly designed to encourage increased judicial employment of existing weapuñs against discovery abuse. See supra note 112.

128. An exception could be made when "manifest injustice" would otherwise result, a standard which the Advisory Committee has stated refers to indigent litigants. See supra note 104. Even if the 
dicial intervention to meet a more substantial burden of persuasion when the costs of resolving the dispute are likely to be high. ${ }^{129}$ Finally, Congress should adopt the list of discovery amendments recently submitted to it by the Supreme Court, ${ }^{130}$ which would require the requesting party's attorney to certify that the discovery request is not intended to harass or delay the opposing side nor to be unduly burdensome or expensive ${ }^{132}$ and which would allow the judge to limit discovery if the information sought is available from a "more convenient, less burdensome, or less expensive" source. ${ }^{132}$

litigant is poor, however, the court should be aware that he has an incentive to abuse the discovery process if the other party has no retaliatory discovery available. See supra p. 372.

129. Ideally, the judge would set the burden of persuasion so that the extra costs of meeting that burden would equal the information-transfer costs that the decision to seek intervention imposes upon the court and the other litigant. This would "internalize" the externality and result in the efficient level of intervention. Ses supra p. 357. No standard tied to either efficiency or distributional concerns currently exists, however.

130. See Greenhouse, Justices Urge Significant Shifts in U.S. Trial Rules, N.Y. Times, May 9, 1983, at A15, col. 1.

131. See proposed rule $26(\mathrm{~g}), 101$ S. Ct. 24 (advance sheet of July 15, 1981) (yellow pages). Violations of the certification provisions would result in mandatory sanctions. Id.

132. See proposed rule $26(\mathrm{~b})$, id. at 23. This standard would allow a judge to use direct intervention to resolve the Prisoner's Dilemma unhindered by the current prohibition on quantitative limitations to discovery of rule $26(\mathrm{~b})$. 